\title{
Klinik ve Radyolojik Olarak Tanısı Zor Konulan Primer Pulmoner Lenfoma Hastalarının Görüntüleme Özellikleri
}

Clinical and Radiological Findings of Misdiagnosed Primary Pulmonary Lymphoma Patients Meral Büyükterzi $^{1}$ (D) , Yunus Yılmazsoy $^{2}$ iD , Serdar Arslan $^{1}$ (D) Vefa Öner ${ }^{1}$ (D) Tuğba Günler $^{3}$ (iD

1 Radyoloji Bölümü, Sağlık Bilimleri Üniversitesi, Konya Eğitim ve Araştırma Hastanesi, Konya/Türkiye

2 Radyoloji Bölümü, Bolu İzzet Baysal Devlet Hastanesi, Bolu/Türkiye

3Tıbbi Patoloji Bölümü, Sağlık Bilimleri Üniversitesi, Konya Eğitim ve Araştırma Hastanesi, Konya/Türkiye

\section{özeT}

AMAÇ: Primer Pulmoner Lenfoma (PPL) klinik bulgular ve görüntüleme yöntemleri ile yüksek oranda yanlış tanı konulan çok nadir görülen bir hastalıktır. Bu çalışmada amacımız, PPL hastalarının klinik, görüntüleme bulguları ve patolojik tanılarını değerlendirerek, yanlış tanı nedenlerini saptamaktır.

GEREÇ VE YÖNTEM: Aralık 2010 - Ocak 2019 yılları arasında histopatolojik olarak PPL tanısı alan 11 hasta retrospektif olarak incelendi. Hastaların klinik bulguları, ön tanıları, ön tanı ile histopatolojik tanı arasında geçen süre ve toraks bilgisayarlı tomografi (BT) bulguları analiz edildi.

BULGULAR: Hastalarda en sık saptanan semptomlar dispne, göğüs ağrısı, öksürük ve ateş idi. Hastaların toraks BT incelemesinde 4 hastada pnömoni benzeri görünüm, 2 hastada tek nodül veya kitle ve 5 hastada da multipl nodüller saptandı. Hastalardan 4 tanesine pnömoni, 2 tanesine akciğer karsinomu ve 5 hastaya ise metastaz ön tanıları konuldu. Yedi hastanın patolojik tanısı diffüz büyük B-hücreli lenfoma, 3 hastanın Hodgkin lenfoma ve 1 hastanın ise MALT lenfoması olarak rapor edildi.

SONUÇ: PPL'nın klinik ve görüntüleme bulguları spesifik değildir. Klinik ve görüntüleme bulguları arasında bir uyumsuzluk varlığında veya uygun tedavi yöntemlerine rağmen klinik olarak yanıt alınamıyorsa, PPL tanısından şüphe edilip biyopsi işlemi uygulanmalıdır.

Anahtar Kelimeler: primer pulmoner lenfoma, bilgisayarlı tomografi, patoloji, malign

\section{ABSTRACT}

OBJECTIVE: The primary pulmonary lymphoma (PPL), very rare disease, was highly misdiagnosed in clinic and imaging methods. We aimed to summarize the clinical, imaging findings and pathological diagnoses of patients with PPL and investigate the causes of misdiagnosis.

MATERIALS \& METHODS: Between December 2010 and January 2019, 11 patients with histopathologically diagnosed PPL were investigated retrospectively. Patients, clinical findings, preliminary diagnoses, time between diagnosis and histopathological diagnosis and thorax computed tomography (CT) findings were analyzed.

RESULTS: The most frequent symptoms of the 11 patients were dyspnea, chest pain, cough and fever. Four patients were pneumonia-like, two patients had lung single nodule or mass and five patients got multiple nodules were detected in thorax CT imaging. Initial diagnosis of patients were pneumonia, lung carcinoma and metastasis in four, two and five cases, retrospectively. There were 7 patients of diffuse large B-cell lymphoma, 3 patients of Hodgkin lymphoma and 1 patient of MALT.

CONCLUSION: The clinical and imaging findings of PPL are nonspecific. If there is a discrepancy between clinical and imaging findings, or if there is no clinical response despite appropriate medical treatment, the diagnosis of PPL should be suspected and biopsy should be performed.

Keywords: primary pulmonary lymphoma, computed tomography, pathology, malignant

\section{GíRiş}

Primer Pulmoner Lenfoma (PPL) nadir görülen bir hastalık olup klinik ve görüntüleme bulguları çok geniş bir spektrum göstermektedir (1). Lenfomaya bağı sekonder pulmoner invazyon çok sık olarak görülür ancak PPL görülme sıklı̆̆ çok azdır. PPL, bütün non-Hodgkin lenfomalar arasında yaklaşık \%1 oranında ve primer pulmoner malign tümörler arasında \%0,3 oranında görülmektedir $(2,3)$. PPL tanım

Yazışma Adresi/Address for Correspondence: Yunus Yılmazsoy, Alpağut Mah. İzzet Baysal Devlet Hastanesi Bulvarı Radyoloji Bölümü Ağaçcılar Mevkii No:72 Bolu/Türkiye

E-Posta/E-Mail: yunusyilmazsoy@gmail.com || Tel: +905325860513

Received/Geliş Tarihi: 25.04.2019 || Accepted/Kabul Tarihi: 15.05.2019

Bu Eser Creative Commons Atıf-Gayriticari 4.0 Uluslararası Lisansı İle Lisanslanmıştır. This work is licensed under a Creative Commons

Attribution-NonCommercial 4.0 International License (CC BY-NC 4.0). 
olarak tanı anında veya sonrasında 3 aya kadar akciğer dışı tutulumu olmayan, akciğer ile sınırlı lenfoma olarak belirtilmiştir (4).

PPL nonspesifik klinik ve görüntüleme bulgularına sahip olması nedeni ile genellikle ön tanısı yanlış konulmaktadır (5). Bu hastalarda semptomların gerilememesi sonucunda biyopsi gibi daha invaziv işlemler uygulanmaktadır (5). Bu hastalara doğru tanı konulması ve tedavisi için klinik ve görüntüleme bulguları iyi analiz edilmeli ve araştırılmalıdır. Bu çalışmada PPL tanısı almış hastaların klinik, görüntüleme bulgularını ve patolojik tanılarını değerlendirerek, yanlış tanı nedenlerini saptamayı amaçladık.

\section{GEREÇ VE YÖNTEM}

Yerel etik kurul onayı alındıktan sonra Aralık 2010 - Ocak 2019 yılları arasında Sağlık Bilimleri Üniversitesi Konya Eğitim ve Araştırma Hastanesinde histopatolojik olarak PPL tanısı alan hastalar geriye dönük olarak incelendi. Çalışmaya dâhil edilme ölçütleri; hastaların 18 yaşından büyük olması, histopatolojik sonuçlarının kesin olarak saptanmış olması, tanı anından 3 ay önce ve sonrasında ekstra-nodal veya ekstra-torakal lenfoma tutulumunu gösteren herhangi bir bulgunun saptanmamış olması ve hastanın daha önceden geçirilmiş lenfoma öyküsünün olmamasıdır.

Hastaların klinik bulguları, laboratuvar sonuçları, ön tanıları, ön tanı ile histopatolojik tanı arasında geçen süre ve toraks bilgisayarlı tomografi (BT) bulguları incelendi. Hastaların BT görüntülemesi multislice 64 kesitli BT (Brilliance CT system; Philips Healthcare, Cleveland, $\mathrm{OH}$ ) cihazı kullanılarak yapıldı. Hastaların pulmoner tutulumları bilateral veya unilateral olarak ayrıldı. Görüntüleme bulgularına göre tek nodül veya kitle, multipl nodül ve pnömoni benzeri görünüm şeklinde sınıflandırıldı. Hastaların toraks BT bulguları toraks radyolojisinde en az 10 yıllık tecrübeye sahip bir radyolog tarafından değerlendirildi. Hastaların histopatolojik sonuçları ve biyopsi yöntemleri ayrı ayrı rapor edildi.

\section{BULGULAR}

PPL tanısı alan toplamda 11 hasta (yaş ortalaması 52,7 \pm 18,7, 24 - 73 yaş) mevcut idi. Bu hastalardan 9 tanesi erkek olup yaş ortalaması 57,4 $\pm 16,9$ ( 26 - 73 yaş), 2 tanesi kadın olup yaş ortalaması 31,5 \pm 10,6 (24 - 39 yaş) olarak hesaplandı. Klinik bulgular arasında hastalarda görülen en sık semptomlar dispne, göğüs ağrısı, öksürük ve ateş idi.
Hastalardan 6 tanesinde laboratuvar tetkiklerinde LDH yüksekliği mevcut idi.

Hastaların toraks BT incelemesinde, en sık saptanan pulmoner tutulum paterni multipl solid nodüler lezyonlar şeklinde idi. Bu hastalarda ön tanı olarak öncelikle metastaz düşüldü. İkinci sırada en sık saptanan görüntüleme bulgusu ise pnömoni benzeri lezyon şeklinde idi (Resim 1). Bu hastalar pnömoni ön tanısı ile uygun antibiyotik tedavisi almalarına rağmen semptomlarında gerileme olmadı. Bu hastalara daha sonrasında biyopsi işlemi uygulandı ve PPL tanısı konuldu. Pnömoni benzeri lezyonu olan 3 hastada aynı zamanda tek tarafı plevral efüzyon mevcut idi. En az rastlanılan toraks BT bulgusu ise tek soliter lezyon idi (Resim 2). Bu hastalara akciğer karsinomu ön tanısı ile biyopsi işlemi uygulandı. Hastaların ön tanı ile histopatolojik tanı arasında geçen süre ortalama 26,6 \pm 10,7 (14 - 43) gün idi. Hastaların ön tanıları, toraks BT bulguları, semptomları ve ön tanı ile patolojik tanı arasında geçen süre tablo 1'de özetlenmiştir.

Resim 1 A-B Primer Pulmoner Lenfoma tanılı 70 yaşında erkek hasta ateş ve öksürük şikâyeti mevcut. Kontrastsız toraks BT tetkikinde sol akciğer üst lobda parasantral yerleşimli içerisinde hava bronkogramları izlenen pnömoni benzeri lezyonu mevcut (beyaz ok). Hastanın histopatolojik tanısı diffüz B-hücreli lenfoma idi.

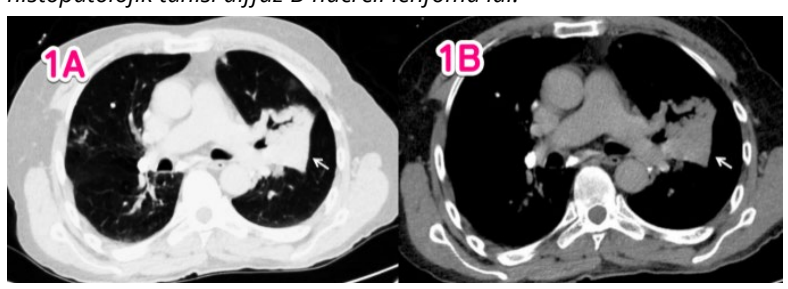

Resim 2 A-B Primer Pulmoner Lenfoma tanılı 54 yaşında erkek hasta dispne şikayeti mevcut. Kontrastlı toraks BT tetkikinde sol akciğer üst lob apikoposterior segmentte anteriorda periferik yerleşimli solid kitle lezyonu mevcut (beyaz ok). Hastanın histopatolojik tanısı MALT lenfoma idi.

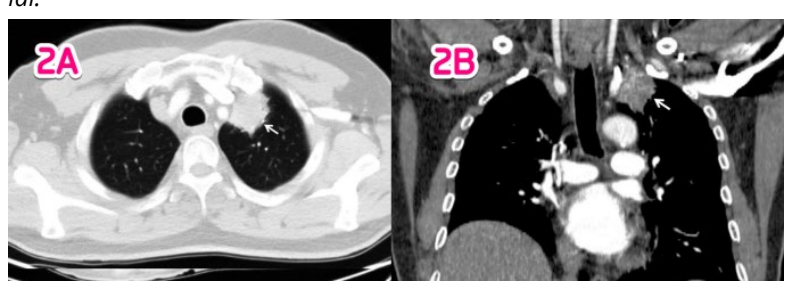

PPL tanılı hastalarda lezyonların lokalizasyonlarına göre farklı biyopsi yöntemleri uygulandı. Bunlardan 5 hastada BT eşliğinde perkütan biyopsi, 5 hastada ultrasonografi eşliğinde peruktan biyopsi ve 1 hastada ise fleksible bronkoskopi ile biyopsi işlemleri uygulandı. Hastaların histopatolojik tanısı 7 hastada diffüz büyük B-hücreli lenfoma, 3 hastada Hodgkin lenfoma ve 1 hastada ise MALT 
lenfoma olarak sonuçlandı. Hastalara uygulanan biyopsi yöntemleri ve histopatolojik sonuçlar tablo $2^{\prime}$ de sunulmuştur.

Tablo 1. Primer Pulmoner Lenfomalı hastaların ön tanıları, toraks BT bulguları, semptomları ve ön tanı ile patolojik tanı arasında geçen süre

\begin{tabular}{|c|c|c|c|c|}
\hline H. & Ön Tanı & Toraks BT Bulguları & Ana Semptom & G.S. \\
\hline 1 & Metastaz & $\begin{array}{l}\text { Bilateral, multiple } \\
\text { nodüler lezyonlar }\end{array}$ & Dispne & 26 \\
\hline 2 & $\begin{array}{c}\text { Akciğer } \\
\text { Karsinomu }\end{array}$ & Tek taraflı soliter kitle & Göğüs Ağrısı & 14 \\
\hline 3 & Metastaz & $\begin{array}{l}\text { Bilateral, multiple } \\
\text { nodüler lezyonlar }\end{array}$ & Göğüs Ağrısı & 25 \\
\hline 4 & Pnömoni & $\begin{array}{l}\text { Tek taraflı, pnömoni } \\
\text { benzeri görünüm ve } \\
\text { plevral efüzyon }\end{array}$ & $\begin{array}{l}\text { Öksürük, Ateş, } \\
\text { Dispne }\end{array}$ & 33 \\
\hline 5 & $\begin{array}{c}\text { Akciğer } \\
\text { Karsinomu }\end{array}$ & Tek taraflı soliter kitle & Dispne & 17 \\
\hline 6 & Pnömoni & $\begin{array}{l}\text { Tek taraflı, pnömoni } \\
\text { benzeri görünüm ve } \\
\text { plevral efüzyon }\end{array}$ & Dispne & 42 \\
\hline 7 & Pnömoni & $\begin{array}{l}\text { Tek taraflı, pnömoni } \\
\text { benzeri görünüm }\end{array}$ & Öksürük, Ateş & 43 \\
\hline 8 & Pnömoni & $\begin{array}{l}\text { Tek taraflı, pnömoni } \\
\text { benzeri görünüm ve } \\
\text { plevral efüzyon }\end{array}$ & $\begin{array}{l}\text { Öksürük, Ateş, } \\
\text { Dispne }\end{array}$ & 38 \\
\hline 9 & Metastaz & $\begin{array}{l}\text { Bilateral, multiple } \\
\text { nodüler lezyonlar }\end{array}$ & Dispne & 18 \\
\hline 10 & Metastaz & $\begin{array}{l}\text { Bilateral, multiple } \\
\text { nodüler lezyonlar }\end{array}$ & Öksürük, Ateş & 16 \\
\hline 11 & Metastaz & $\begin{array}{l}\text { Tek taraflı, multiple } \\
\text { nodüler lezyonlar }\end{array}$ & Göğüs Ağrısı & 21 \\
\hline
\end{tabular}

H: Hastalar G.S. :Ön Tanı - Patolojik Tanı Arasında Geçen Süre (gün)

Tablo 2. Primer Pulmoner Lenfomalı hastalara uygulanan biyopsi yöntemleri ve hastaların patolojik tipleri

\begin{tabular}{|ccc|}
\hline Biyopsi Yöntemi & Hasta Sayısı & $\%$ \\
BT eşliğinde perkütan biyopsi & 5 & 45,4 \\
US eşliğinde perkütan biyopsi & 5 & 45,4 \\
Bronkoskopi & 1 & 9 \\
Patolojik Tipler & & \\
Diffüz Büyük B-Hücreli Lenfoma & 7 & 63,6 \\
Hodgkin Lenfoma & 3 & 27,2 \\
MALT & 1 & 9 \\
\hline
\end{tabular}

BT: Bilgisayarlı Tomografi, US: Ultrasonografi

\section{TARTIŞMA}

PPL çok nadir görülmesi ve spesifik klinik ve görüntüleme bulgusunun olmaması nedeni ile tanısı zor konulan bir hastalıktır. PPL genellikle yaşlı hastalarda görülmekte olup 50 yaşın üzerinde ve erkek hastalarda daha sık olarak ortaya çıkmaktadır (6). Çalışmamızda hastalarımızın büyük bir kısmı $(\% 63,6) 50$ yaşın üstünde olup yaş ortalaması 52,7 $\pm 18,7$ idi. Erkek hastalarımızın kadın hastalarımıza oranı ise 4,5:1 olarak hesaplandı.

PPL klinik bulguları literatürde farklı çalışmalarda farklılıklar göstermektedir (7). Çalışmalarda en sık görülen semptomlar arasında dispne, ateş, hemoptizi, göğüs ağrısı ve öksürük gibi nonspesifik semptomlar rapor edilmiştir $(5,8)$. Bu semptomların yanı sıra bazı hastalar asemptomatik olup klinik bulgu ortaya çıkmayabilir (9). Çalışmamızda bütün hastalarımız semptomatik olup en sık görülen semptomlar dispne, göğüs ağrısı, öksürük ve ateş idi.

PPL görüntüleme bulguları literatürde genel olarak üç grupta sınıflandırılmaktadır. Bunlardan ilki, nodül veya kitle görünümlü lezyonlardır. Bu lezyonlar soliter veya multipl olabilir. Tek veya bilateral akciğer tutulumu gösterebilir (10). $\mathrm{Bu}$ lezyonlar genellikle akciğer karsinomu veya metastaz ile karışmaktadır. Çalışmamızda 7 hastada $(\% 63,6)$ toraks BT tetkikinde soliter veya multipl nodül şeklinde lezyonlar saptandı. İkinci saptanan patern ise pnömoni veya konsolidasyon gibi görüntüleme bulguları olan lezyonlar oluşturmaktadır. Bu lezyonlar içerisinde hava bronkogramları veya nadiren de kavitasyonlar saptanabilir. Genellikle lobar pnömoni gibi bulgu verirler (11). Çalışmamızda 4 hastada $(\% 36,3)$ toraks BT bulguları pnömoni benzeri görünüme sahipti ve hava bronkogramları mevcuttu. 3 hastada bu bulgulara ek olarak plevral efüzyon eşlik etmekte idi. Son olarak bu hastalarda nadir olarak mikst tip pulmoner tutulum paterni saptanabilir. Mikst tip tutulum paterni ise interstisyel pnömoni bulguları ve yaygın infiltrasyon ile seyretmektedir $(10,11)$. Çalışmamızda hiçbir hastada mikst paternde akciğer parankim tutulumu saptanmamıştır.

PPL histopatolojik olarak farklı tiplerde görülmektedir. Literatürde en sık saptanan patolojik tip MALT lenfoma olarak bildirilmiştir $(12,13)$. Yao ve ark. yapmış oldukları bir çalışmada PPL tanılı hastalarda en sık MALT Ienfoma \%63,2 oranında saptamışlardır (5). Graham ve ark. yapmış oldukları bir diğer çalışmada ise en sık MALT lenfoma saptanmış olup bu oran \%70 olarak rapor edilmiştir (14). Bununla birlikte diffüz büyük B-hücreli lenfoma literatürde ikinci en sık saptanan PPL patolojik tipi olarak bildirilmiştir (15). Çalışmamızda en sık saptanan PPL patolojik tipi diffüz büyük B-hücreli lenfoma olup \%63,6 oranında saptandı. MALT lenfoma ise sadece 1 hastada (\%9) mevcut idi.

Çalışmamızın bazı kısıtlılıkları mevcuttu. Bunlardan ilki çalışmamızın dizaynının retrospektif olması idi. Hasta sayısının az olması diğer önemli bir kısıtlılık idi. Hastalığın çok nadir görülmesi bu kısıtlılığın en önemli sebebini oluşturdu. Son olarak da hastaların büyük çoğunluğunun tanı konulduktan sonraki takiplerinin elimizde mevcut 
olmaması hastaların prognozu ve sağ kalımları hakkında detaylı analiz yapamamamıza neden oldu.

Sonuç olarak, PPL çok nadir görülen, klinik ve görüntüleme bulguları ile tanı konulması zor önemli bir hastalıktır. Klinik ve görüntüleme bulguları arasında bir uyumsuzluk varlığında veya uygun tedavi yöntemlerine rağmen klinik olarak yanıt alınamıyorsa, PPL tanısından şüphe edilip biyopsi işlemi uygulanmalı veya biyopsiler tekrar edilmelidir. Bu hastalığın kesin tanısı ancak histopatolojik inceleme ile konulabilmektedir.

Yazarlar arasında çıkar çatışması yoktur.

The author declares no conflict of interest.

Finansal Destek: yoktur / Funding : none

doi: https://doi.org/10.33713/egetbd.558060

\section{KAYNAKLAR}

1. Borie R, Wislez M, Thabut G, Antoine M, Rabbat A, Couderc LJ, et al. Clinical characteristics and prognostic factors of pulmonary MALT Iymphoma. Eur Respir J 2009;34(6):1408-16.

2. Nahorecki A, Chabowski M, Straszak E, Teplicki A, Szuba A, Langfort $\mathrm{R}$, et al. Primary pulmonary MALT lymphoma - case report and literature overview. Eur Rev Med Pharmacol Sci 2016;20(10):2065-9.

3. Poletti V, Ravaglia C, Tomassetti S, Gurioli C, Casoni G, Asioli $\mathrm{S}$, et al. Lymphoproliferative lung disorders: clinicopathological aspects. Eur Respir Rev 2013;22(130):427-36.

4. Ankita G, Shashi D. Pulmonary Lymphomatoid Granulomatosis- a Case Report with Review of Literature. Indian J Surg Oncol 2016;7(4):484-7.

5. Yao D, Zhang L, Wu PL, Gu XL, Chen YF, Wang LX, et al. Clinical and misdiagnosed analysis of primary pulmonary lymphoma: a retrospective study. BMC Cancer 2018;18(1):281.

6. Cordier JF, Chailleux E, Lauque D, Reynaud-Gaubert M, Dietemann-Molard A, Dalphin JC, et al. Primary pulmonary lymphomas. A clinical study of 70 cases in nonimmunocompromised patients. Chest 1993;103(1):201-8.

7. Sirajuddin A, Raparia K, Lewis VA, Franks TJ, Dhand S, Galvin JR, et al. Primary Pulmonary Lymphoid Lesions: Radiologic and Pathologic Findings. Radiographics 2016;36(1):53-70.

8. Zhang $X Y$, Gu DM, Guo JJ, Su QQ, Chen YB. Primary Pulmonary Lymphoma: A Retrospective Analysis of 27 Cases in a Single Tertiary Hospital. Am J Med Sci 2019;357(4):316-22.

9. Lluch-Garcia R, Briones-Gomez A, Castellano EM, SanchezToril F, Lopez A, Brotons B. Primary pulmonary Hodgkin's lymphoma. Can Respir J 2010;17(6):e106-8.

10. North LB, Libshitz HI, Lorigan JG. Thoracic lymphoma. Radiol Clin North Am 1990;28(4):745-62.
11. King LJ, Padley SP, Wotherspoon AC, Nicholson AG. Pulmonary MALT lymphoma: imaging findings in 24 cases. Eur Radiol 2000;10(12):1932-8.

12. Pagani M, Antico A, Bellarosa S, Cavazzini G, Aitini E. Primary pulmonary high grade non-Hodgkin's lymphoma in an elderly patient. A case report. Tumori 2007;93(6):622-4.

13. Tanriverdi E, Acat M, Ozgul G, Abbasli K, Gul S, Yasar Z, et al. Primary pulmonary lymphoma: four different and unusual radiologic and clinical manifestations. Leuk Lymphoma 2017;58(5):1231-3.

14. Graham BB, Mathisen DJ, Mark EJ, Takvorian RW. Primary pulmonary lymphoma. Ann Thorac Surg 2005;80(4):1248-53.

15. Zhu Z, Liu W, Mamlouk O, O'Donnell JE, Sen D, Avezbakiyev B. Primary Pulmonary Diffuse Large B Cell Non-Hodgkin's Lymphoma: A Case Report and Literature Review. Am J Case Rep 2017;18:286-90. 